\title{
A Lesson Plan For Sustainability In Higher Education
}

Elizabeth Driscoll, Oracle Corporation, USA

Clare L. Comm, University of Massachusetts Lowell, USA

Dennis F. X. Mathaisel, Babson College, USA

\begin{abstract}
Much anxiety surrounds the future of higher education in the United States. With escalating costs, tuition, and class sizes, and the increasing exclusion of many poor and minority students, higher education needs to become more accessible and sustainable. This paper defines five "abilities" for the sustainability of higher education - availability, dependability, capability, affordability, and marketability. The literature indicates that components of each of these abilities are lacking at many institutions. To remedy this problem, the authors developed a framework for sustainability based on these five abilities, and a case study at a public university in the United States was used to validate the framework's applicability to education.
\end{abstract}

Keywords: Framework for Sustainability; Sustainable Abilities; Higher Education Sustainability; University Sustainability

\section{INTRODUCTION}

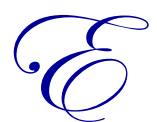

ducation is an important investment for a sustainable society. Higher education is also a business enterprise which needs to market and communicate its competitive advantages to endure and succeed. This enterprise needs to communicate areas of interest to future students and faculty, and each institution needs to define its position in the marketplace. Why should potential students attend a specific college or university? What can the institution offer the community? What abilities must a college/university have that will allow the institution to endure or sustain itself?

Sustainability is the "ability" to endure. For any entity or enterprise, sustainability is the ability to remain productive long term while minimizing waste and creating value (Wikipedia, 2010). The entity or enterprise, whether it is an ecological, environmental, human, or service enterprise, must possess five abilities to be sustainable - availability, dependability, capability, affordability, and marketability (Mathaisel et al, 2009). This paper presents a framework for sustainability in higher education based on these five abilities.

\section{Higher Education in the United States}

In the United States, higher education can be described as vocationally-oriented (Westmeyer, 1985). Even though historically some universities taught liberal arts-based education without job preparation as the main goal, most institutions prepared workers for "generic" jobs in the real world. The modern university was established to meet the codependent needs of the new industrial economy and emerging nation-states (Taylor, 2010). At the beginning of the $20^{\text {th }}$ century, fewer than $5 \%$ of America's 18 -year olds attended college. There were fewer than a thousand colleges and universities; only 38 offered doctoral degrees and there was no such thing as a community college (Levine, 1994). Since 1911, the United States has moved from a system of higher education that was open to a small proportion of the population, and largely peripheral to the economic activities of the country, to a system of higher education offering access to all high school graduates and functioning at the center of the nation's economic, social and political life (Levine, 1994). By the end of World War II, half of the students in American colleges and universities were in privately controlled institutions (Riesman, 1998). In the years following World War II, increasing prosperity and enlightened government policies led to rapidly expanding undergraduate programs 
that created new opportunities for countless young people (Taylor, 2010). Clark Kerr, former president of the University of California and the person most instrumental in creating the modern American system of higher education, modernized and mass produced the research university (Levine, 1994). Now there are more than 4,000 degree-granting higher education institutions in the United States (Digest of Educational Statistics, 2004).

From 1999 to 2009, higher education experienced a "lost decade", according to Jeff Selingo who is the editorial director at The Chronicle of Higher Education (2012). Those years saw a surge in students pursuing higher education, driven partly by colleges that advertised heavily and created new academic programs, services, and fancy facilities.

\section{Problems with Higher Education in the U.S.}

In a February 2009 address to Congress, President Obama urged all Americans to pursue "a year or more" of higher education, or career training, and set a goal for the nation to have the world's highest proportion of college graduates by 2020 . Education, said Mr. Obama, who has proposed spending $\$ 12$ billion to improve programs, courses, and facilities at community colleges, is one of "three areas that are absolutely critical to our economic future (Fischer, 2009)." Universities play a pivotal role in society. They are hubs of innovation. They attract and develop talent. They provide a free and critical voice. They create and share new knowledge and enrich the arts. They are crucial assets in metropolitan and regional economies. They link the local and global. They do all these things with varying degrees of commitment and success, depending on the political and financial contexts in which they find themselves. No other institution provides an array of social benefits and few have shown comparable ingenuity and determination to survive like higher education (Ellis, 2010). Education is a human right and higher education prepares graduates to face social, cultural, economic, and global challenges through research, classroom discussions, mentoring and concentrated degrees. Higher education creates the ability to sift through misinformation and form individual problem-solving, world-changing solutions.

According to Mark C. Taylor, author of Crisis on Campus: A Bold Plan for Reforming Our Colleges and Universities, "The higher education system is broken and needs to be overhauled (Taylor, 2010)." Quality in higher education is declining and colleges and universities are not adequately preparing students for life in a rapidly changing and increasingly competitive world (Taylor, 2010). Learning, developing, and perfecting new skills are vital to success in our ever-changing global economy.

The rapid changes of the last century have pushed the globe into an emerging network culture and the network revolution is displacing industrial \& consumer capitalism with global financial capitalism. Thus, a new information and communication infrastructure has been developed (Taylor, 2010). The Internet and World Wide Web gave way to this new infrastructure. How information is delivered is changing and this transformation poses a great challenge and opportunity for higher education in America. The ways we communicate have also drastically changed, and higher education needs to adopt these new means of communication to achieve sustainability. As networks expand and more people and institutions are connected, everything speeds up and the stakes grow higher. Networks operate openly, so universities should operate openly (Taylor, 2010). Increasingly fragmented curriculums, compounded with expensive tuition rates, are leaving students wondering if institutions of higher education are needed to be successful (Taylor, 2010). There is a common relationship between the financial bubble and education bubble. The value of college and university assets has plummeted. Debts are increasing. Costs continue to climb. In a recent Pew Research Center poll (2011) of 2,142 adults, 75\% of Americans think a college education has become too expensive for most people, and only 55\% of higher education graduates think college prepares them for a job. Hence, this service is becoming unaffordable and of questionable value to some students.

Peter Drucker, business consultant and management guru, continues with the same idea, stating "Thirty years from now the big university campuses will be relics. Universities won't survive [unless a radical change is made]. It's as large a change as when we first got the printed book. The cost of higher education has risen as fast as the cost of health care, and for the middle-class family, college education for their children is as much of a necessity as is medical care; without it, the children have no future. Such totally uncontrollable expenditures, without any visible improvement in either the content or the quality of education, means that the system is rapidly becoming untenable. Higher education is in deep crisis (Lenzner, 2007)." 
Looking at higher education from a government perspective, there is much wasteful spending of money. For example, state and the federal governments do not offer college incentives for success and demand little accountability from them (Leonhardt, 2011). Basically, colleges receive government money based on student enrollment and not on graduation rates. So, many students who enroll in college do not graduate. The focus of some of the $\$ 12$ billion to improve education should be on raising the U.S. college graduation rate. In the last decade, countries like Japan have surpassed the U.S. graduation rate of $50 \%$ and many other countries are approaching it (Leonhardt, 2011).

However, in many ways, the United States remains pre-eminent. Its scholarly papers are still the most cited and it remains the top destination for foreign students. American universities dominate international college rankings. When countries like China, Korea, and Singapore seek to build up their higher education systems, their model is the United States. "The United States is overwhelmingly the reference point for what they want to happen", says Aims C. McGuinness, Jr., a senior associate at the National Center for Higher Education Management Systems, who has advised both states and countries on educational reform (Fischer, 2009). However, can and will this preeminence continue? In a recent Pew Research Center poll (2011) of 1,055 university presidents, only 19\% rated the U.S. higher education system as best in the world and $51 \%$ rated it as one of the best in the world, with concerns that ten years from now the ratings may be lower.

For-profit educational institutions add to problems in higher education because faculty academic freedom is nearly meaningless and tuition is no bargain for students (Auxter, 2010). Corporations are purchasing and refurbishing for-profit institutions to make a profit while trying to prove that traditional higher education is obsolete. However, with lower graduation rates and little employment information about their graduates, for-profit universities lack academic accountability. Heavy branding and advertising campaigns portray for-profits as the higher education choices for the next generation of students. Financially, almost half of federal loan borrowers in for-profit colleges defaulted within the first two years of loan repayments by 2009 (Auxter, 2010). This leads to the belief that for-profit education is not producing well-rounded students nor attracting research-driven and knowledgemotivated faculty.

As stated previously, higher education is a business. Education should be treated as a marketable service with qualified, knowledgeable graduates who will contribute positively to society. To the student, higher education is a means to employment. In most cases, it is a means to employment that is more fruitful financially than with just a high school diploma (Eddy, 1998). However, at the graduate level, some universities are producing a product for which there is no market - i.e., candidates for various teaching positions that do not exist (Taylor, 2010). In addition, $\mathrm{PhD}$ and Masters Programs, in some cases, have become extremely lengthy. Graduates may not finish the programs until their thirties, with debt surmounting the price of an average home and without the guarantee of a job (Taylor, 2010). Even when economic conditions are generally prosperous, economic insecurity afflicts well educated and highly experienced members of the US labor force (Lazonick, 2009). Each institution of higher education needs to develop and communicate its competitive advantages to endure. Clear, definable goals, strong leadership, and keen communication plans are needed to achieve sustainability. The application of five essential abilities will illustrate how higher education can achieve this goal of sustainability.

\section{A FRAMEWORK FOR SUSTAINABILITY}

In ecology, sustainability describes how biological species survive. For the environment, it is assessing whether or not project outputs can be produced without permanent and unacceptable changes in the environment. For humans, it is our long-term physical and cultural well-being. For mechanical systems and structures, it is maximizing reliability while conserving required resources and reducing waste. Sustainability and sustainable development have become popular goals. They have also become wide-ranging terms applicable to any entity or enterprise on a local or a global scale for long time periods. Sustainability has many interpretations. Recently, the term has been used more in the context of "green", which refers to having "no negative impact on the global or local environment, community, society, or economy (Mathaisel et al, 2009)." However, the traditional meaning centers around the words "endure", "maintain", or "support", which is the focus of this paper. Here, sustainability means to aim to maintain the readiness and operational capability of systems or services in the entity through the adoption of a strategy or plan for sustainability that meets established performance requirements in the most effective and efficient 
manner over the entity's life cycle. The scope varies among entities, of course, but it does include the key word "ability". Thus, to be sustainable, an enterprise must possess the five abilities illustrated in Figure 1.

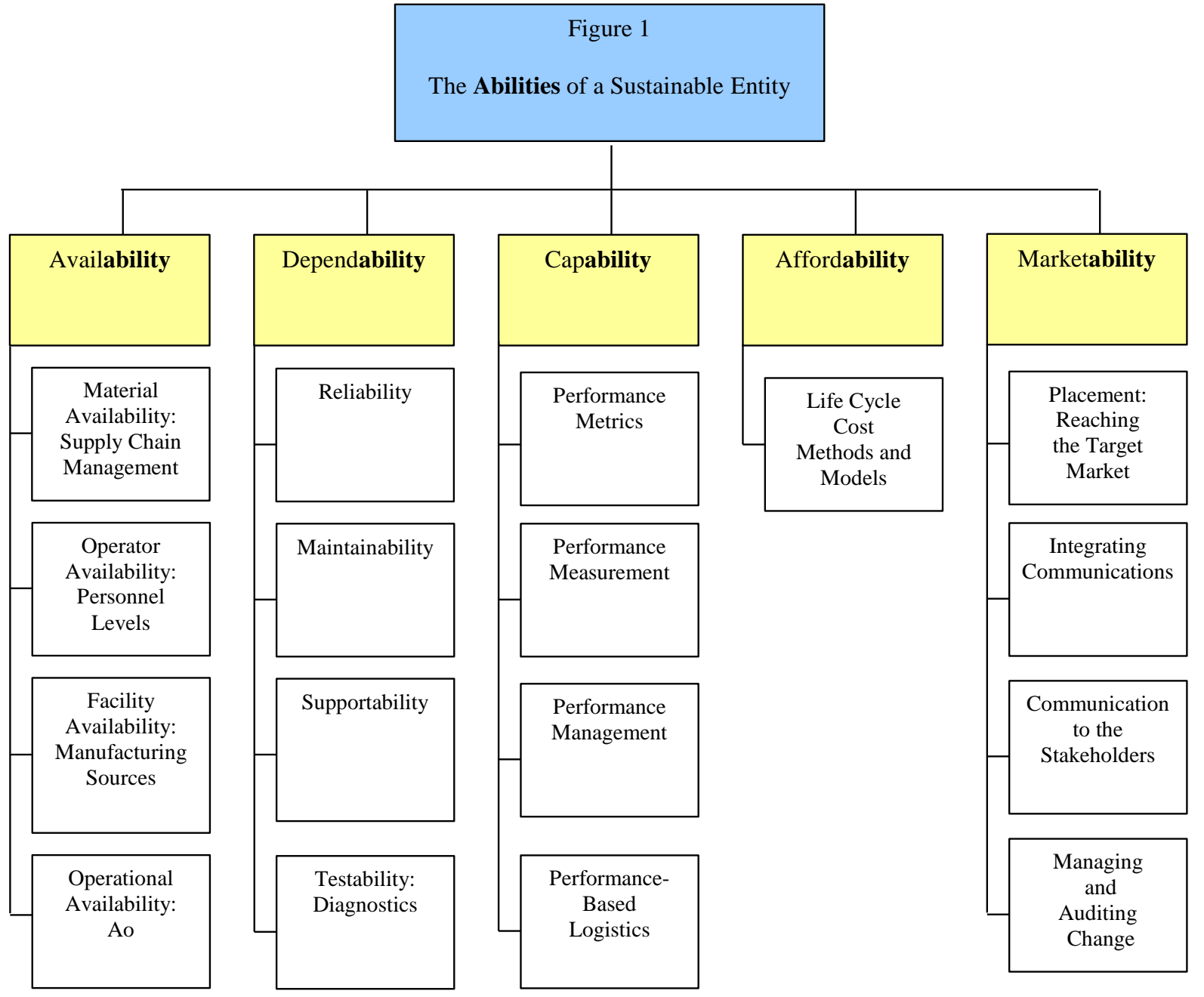

Figure 1: The Abilities of a Sustainable Entity

Sustainment strategies must evolve. Implementation is not quick, nor is the design initially structured for all possible future outcomes. Strategic refinement is necessary throughout the entity's life cycle, particularly during its development, its modifications, its implementation, and its upgrades (Mathaisel et al, 2009).

\section{Availability}

Availability is the ability to access to the right technology, materials, facilities, tools, and people that makes sustainability possible. It is also the long-run operational availability of the services or products of the entity (Mathaisel et al, 2009). The accelerating rate of globalization will make it necessary to learn about other societies and cultures (Taylor, 2010). Additionally, access to higher education is unevenly spread across demographics (Altbach, 1999). Accessibility needs to grow among various demographics while integrating global studies to achieve sustainability. 
Availability to higher education in the United States has become a problem due to expensive tuition costs and access to physical campuses. More and more students are working and enrolling in higher education classes simultaneously, so balancing on-campus courses has become challenging. However, the introduction of online education has increased the availability of education across the globe. From Fall 2002 to Fall 2007, online enrollment in degree-granting post-secondary institutions increased from 1,602,970 (9\% of total enrollment) to 3,939,111 (21.9\%) (Taylor, 2010). The online education phenomena is expanding target markets and allowing universities to better reach these target markets - a key component of sustainability. Online education may also allow for further availability across other demographics, satisfying another component of endurance.

In addition, online education is an example of innovation mixed with flexibility - another key component of sustainability. The use of information and communication technology in higher education makes it possible for universities to offer students much more flexible access to learning resources, administrative services, and academic staff, but it also encourages students to expect such flexibility (Ellis, 2010). According to Mark Taylor, information needs to be available for America to grow in the global world (Taylor, 2010) and the invention of online learning provides the means to learn and teach globally. In some cases, online classes are less expensive than on-campus classes, so online education provides a less-expensive means to a degree as well.

To endure, a university must be flexible in its course content. Basic principles classes are still needed for a well-rounded understanding, but colleges and universities must offer classes that reflect new trends and technology. If there is a specific need in the job market for a specific set of skills, higher education should provide classes and degrees that will prepare students with the knowledge to succeed in this field. For example, entrepreneurship classes in MBA programs are becoming more popular because students and potential students are showing an interest in starting their own businesses. So, if there is a demand for such classes, universities must remain open and flexible to meet this demand. Universities must also create easy access to these classes across all demographics.

Additionally, autonomy in education is vital to sustainability. This is the freedom of universities to select staff and students and to determine the conditions under which they remain in the university, freedom of universities to determine curriculum content and degree standards, and freedom of universities to allocate funds across different category expenditures (Altbach, 1999). For example, biotechnology is growing in New England and there has been a recent push for biotechnology research at both public and private New England institutions. New buildings and labs are being constructed to accommodate the specific need for this research. The freedom of colleges and universities to fund these buildings allows the institutions to flex their autonomy while meeting market demand.

\section{Dependability}

Dependability refers to the reliability, maintainability, supportability and consistency of the services or products. Students must be able to rely on a university to deliver the tools for success, whether it is through their career placement center or with better understanding of specific subject material. The higher education system is sustained by the ingenuity and passion of those who have chosen an academic life (Ellis, 2010). Students depend on teachers and mentors for their education. Colleges and universities need to ensure that the quality of their service, education, and research produces well-educated graduates.

Teaching and research are intrinsically linked (Taylor, 2010) and research support is another road to sustainability. According to Bob Forrant, educator, "For universities to stimulate sustainable growth, they must focus on creation of new knowledge, preservation of indigenous knowledge, dissemination of both types of information, economic and social innovation, the resolution of problems associated with rapid globalization and urbanization, and the development of strong community-based organization (Forrant, 2002)." The ability to stimulate sustainable growth thrives on the clear definition of the institution's goals and support of the various strategies from the researchers and educators. Continuous research, and evaluation of research, is needed for strategy and goal maintenance.

Commitment to education and research promotes movement toward the institution's defined goals. Tenure was established for professors to express their educational ideas through teaching and research without the concern of losing their jobs. Tenure furnishes universities and colleges with the reliable mentors and educators they need to 
resolve social and economic problems and endure. Currently, 35\% of college/university positions are tenured or tenure-track (Taylor, 2010). However, tenured professors still need to be held accountable for their actions. According to the National Commission on Research, "When well designed, the system of accountability involves an appropriate balance between independence and control, between incentives and constraints, and between the costs and benefits of the various procedures and requirements used (Altbach, 1999)."

In terms of maintainability, universities should produce education for mass consumption (Taylor, 2010). Degrees are more specialized and the number of degrees offered at universities is expanding. Even so, institutions of higher education need to offer a range of degrees to maintain dependability in the market. Potential students need to depend on the university to offer traditional degrees as well as new, specialized degrees.

With respect to supportability, Charles M. Vest, president of the National Academy of Engineering and former president of the Massachusetts Institute of Technology, says that China, Korea, and Singapore are engaging in major efforts to build higher education. In the U.S., he says, the same sense of urgency does not exist. He compares the situation to the obliviousness of American manufacturing during the time Japan was building its industry (Fischer, 2009). The need for government support is the base of Vest's argument. Public policy supporting the importance and dependability of higher education will certainly give higher education the ability to endure.

\section{Capability}

Capability is about performance metrics, measures, and management. One measure of the effectiveness of a university is linking a graduate's specific degree to the success in his/her career. In addition, one can measure the capability of a university to produce reliable outcomes by the effectiveness of the institution's leadership. To be sustainable, universities must be capable of preparing students for successful careers. Learning is the basis of higher education. An institution's ability to prepare its graduates to tackle problems is crucial to success. A proven track record of successful graduates not only indicates a university's capability to provide a successful service, but also establishes its roots for future growth.

Sustainable leadership matters. It preserves, protects and promotes deep and broad learning for all in caring relationships. Leadership becomes central to management (Hargreaves, 2006). Effective leadership is one of the foundations of a sustainable institution. Effective leadership, meaning the ability to communicate the institution's goals, wisely taking action to achieve these goals, and communicating successes to the student body and faculty, while continually planning for the future, is the vehicle driving a sustainable institution. According to Professor Robert Ellis, "Clever leadership, design and management can create an ecosystem which adapts to change, improves through learning, learns through experience, and can bring itself back into balance through the efficient working of its own internal processes (Ellis, 2010)." Sustainable leadership lasts. It preserves and advances the most valuable aspects of learning and life over time, year upon year, from one leader to the next (Hargreaves, 2006)." Leaders should communicate their skills and ideas to future leaders so the learning and prospering process can continue. Information sharing encourages further growth. Leaders can do this in the form of policies, politics, written works, and through productive faculty.

Recently, in the United States, university leaders have been criticized for moving too slowly to position their schools for a changing world. An example was the dismissal and then reinstatement of the President of the University of Virginia for these reasons. Consequently, college presidents need to embrace technology as a means of improving student learning.

\section{Affordability}

Affordability focuses on life-cycle cost. It's no secret that college has become expensive and, in many cases, unaffordable. According to the Center for College Affordability and Productivity, "Since 1980, the average real cost of attending a 4-year public institution (tuition, fees, and room and board) has more than doubled, going from $\$ 6,300$ per year to just over $\$ 14,000$ in 2009 . At private institutions, the real cost has gone up by close to $150 \%$ in the same period, rising from $\$ 13,700$ per year to $\$ 33,400 "$, as shown in Figure 2 (Center for College Affordability and Productivity, 2010). 


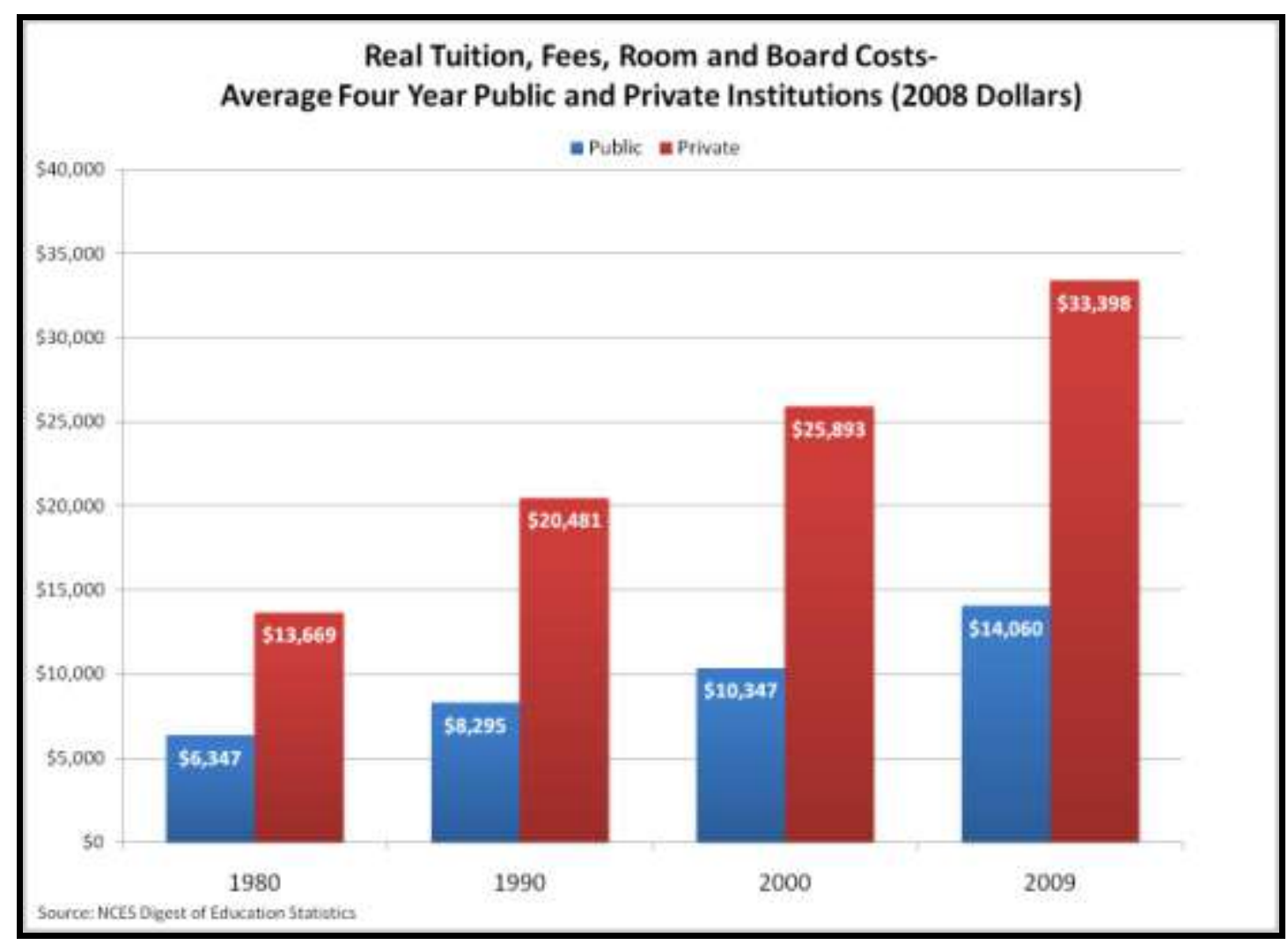

Figure 2: Rise in Real College Costs

Source: The Center for College Affordability and Productivity (2010)

The financial assets of a university are the bottom line for endurance. Depletion of these assets would have dire effects. Simply stated, with no financial assets, there is no future. For example, a well-known, traditional private institution may not have sufficient life-cycle liquid assets to cover its staggering debt if another crisis occurs. Financial cutbacks may not be enough to support this entity. So, a number of consequences can happen - the private university can close its doors, seek a government bailout, or sell the debt to another country, which would assume control over the university (Taylor, 2010). The problem for this institution lies in its old traditional ways of thinking. This inhibits the private institution from adapting quickly to the environment, and reputation alone cannot sustain a university.

Increasing unaffordable tuition rates are the main life-cycle problem for higher education in the United States. For this enterprise to achieve sustainability, it must become more affordable for future prospects. It must become available to students who do not have the financial means to attend college. It must be able to provide a quality education while reducing the life-cycle cost of its services. Higher education cannot totally depend on government subsidized student loans, scholarships, and Pell grants to offset its high costs.

\section{Marketability}

Marketability is defining a market for products or services, understanding consumer needs, managing change over time, identifying improvements for the benefit of the stakeholders, and selling sustainability concepts to those resistant to change (Mathaisel et al, 2009). Plans to change and develop must start with clear, achievable goals. It is the responsibility of the leadership to determine the campaign's mission, what new image is required, and later judge whether the set goals are being met (Gregory, 1993). For an educational institution, it should not be the goal to just increase the financial bottom line. Each institution of higher education must define its sustainable knowledge-based competitive advantage and pursue a marketing plan for this advantage. Properly communicating the competitive advantage, while managing change, will lead to sustainability. 
Reputation can be a result of a clearly defined competitive advantage. Reputation is the institution's image from the community's point of view; it can also be the global image of the institution. First, corporate image begins with the perception of the company and the perception is reality to the public (Gregory, 1993). However, reputation is not enough to ensure sustainability. As Dr. Jacqueline Moloney, Executive Vice Chancellor of the University of Massachusetts Lowell, states, "When developing a business plan for the future, having a reputation wasn't a sustainable model. We needed to develop a keen business plan in a more entrepreneurial, business disciplined way (2010)."

Goals give purpose to ventures (Hostrop, 1983) and the competitive advantage can provide the means to achieve goals. For example, one leading public institution boasts baseball research in its engineering department. This is a great competitive advantage over other institutions because this institution offers interesting, applicable research that others do not. As stated previously, education is a marketable service and students and graduates are its products. This service's products are generating useful, timely, and applicable research, and capitalizing on this differentiation will plant the roots for growth. In addition to offering research results from its latest projects, students in this example can sponsor summer athletic camps, offer advice to coaches and teams, host seminars, and develop an NCAA research panel.

Image advertising, when properly executed, can dramatically help to move a corporation toward meeting its goals. It is, in fact, the very leading edge of corporate strategy, essential in positioning a company for maximum growth (Gregory, 1993). Image advertising is related to branding, which is communicating and identifying the identity of a product, service or business. In treating universities and colleges as businesses, the following goals of image advertising can be utilized (Gregory, 1993):

1. Building public awareness and acceptance and establishing a more favorable market position

2. Redefining your corporation after a merger, takeover, acquisition, or name change

3. $\quad$ Pre-selling target markets to support product marketing

4. Influencing shareholders and the financial community

5. Establishing your company's position on timely issues

6. Assisting in the management of a crisis situation

7. Attracting and keeping quality employees, while creating a cooperative environment in their communities.

The corporate image can make or break the sustainability of a university. This corporate image will accompany the new faculty and research and breakthroughs that a university produces. Obviously, it should relate to the university's innovations. It's the corporate image that's ultimately going to sustain a university. In addition, only through corporate advertising can a company or institution of higher education publicly express their uncensored, unedited views about the society in which they operate and the events that affect their prosperity (Gregory, 1993).

Further, a critical ingredient is an enterprise's ability to resist duplication by its competitors (Mazzarol, 2001). The competition in higher education is not just international, but national, as states and institutions vie with one another for talent and resources. Universities in states that are weathering the current recession, for example, may take the opportunity to poach top researchers from institutions in hard-hit states. Such actions might benefit individual states but not the country's relative position (Fischer, 2009).

\section{A CASE STUDY IN APPLYING A LESSON PLAN FOR SUSTAINABILITY}

Dr. Jacqueline Moloney, Executive Vice Chancellor of University of Massachusetts Lowell (UML), revealed that the key to sustainability is a keen business plan with strict measurements and flexibility to adopt new trends and changes. Sustainability strategies should include a business plan, cost controlling measures, and idea development for generating more revenue. Additionally, branding leads to success. Visibly and consistently communicating the university's logo, colors, and tagline creates a certain "package" for UML - world-class higher education, viable research, career services, continuing education, variety of facilities, and a trusted, branded name. UML experienced a huge turnaround in the late 1990s when they were informally dubbed as higher education's "best kept secret." The Continuing Studies department at UML was a major player in the turnaround of the university. The department grew from a $\$ 4$ million operation to over $\$ 28$ million. 
Success in the Continuing Education Department stemmed from building a business plan in a more entrepreneurial way. According to Moloney, "We had to be business disciplined and we needed to look at strategic directions. You have to be smart and business disciplined to be sustainable." Moloney's team consistently met goals by using finances as benchmarks and constantly reviewing the entire planning process, which was transparent. This open environment empowered the team to set and reach higher goals. In her new position as Executive Vice Chancellor, Moloney was able to apply the same business practices to tackle the university's deficit. There was massive cost cutting the first year. To achieve their goal, they had to cut costs and keep a focus on the core mission. Again, the entire planning and budget process was transparent. UML created a strategic planning commission consisting of over 200 faculty and staff to oversee planning and budgeting. The process was managed and monitored constantly, which allowed the university to stay on target. UML openly recognizes the high price tag for education, especially graduate education, so they are investing more in teaching assistants (TAs), internships and financial aid packages for students to help lighten their financial burdens. Over $70 \%$ of undergraduate students at UML receive financial aid.

Moloney recognized that the answer to sustainability is branding and UML began branding itself with a new logo, marketing team, and public relations firm to communicate the competitive advantages of UML. They also have a business savvy team to negotiate contracts with UML suppliers and business partners, such as Aramark, for their food services. Strong business partnerships with profitable contracts are another measure of financial sustainability. UML recently purchased the Doubletree Hotel, now known as UMass Lowell's Inn \& Conference Center (ICC), and the Tsongas Arena, now known as the Tsongas Center. Branding and advertising strategies, as well as financial plans for these properties, were carefully planned and executed. As Moloney states, "You don't just make a plan and spend the money. You need to figure out how you're going to pay for it by generating new revenue." Controlling expenses is vital to financial sustainability. Commercial ventures and intellectual property are also important for financial sustainability because they preserve and generate future revenue. The acquisition of the ICC increased on-campus undergraduate living from $25 \%$ to $40 \%$. It also offers the university a facility to display research while acting as a revenue generator.

Another example of UML focusing on the student learning experience is the future removal of mega sections in the College of Management. Research shows that students participate more and receive more educational value in smaller classrooms. There is more intimacy in smaller classrooms. Consequently, this should lead to student retention, which translates to sustainability.

Regarding visibility and maintainability, Moloney states," We weren't there ten years ago; hoping people would figure out that we have a great university with a lot to offer. Having a reputation isn't enough, and it isn't a sustainable model." Moloney continues that the bottom line or main goal of UML is to increase student retention while adding value for the students. To date, enrollments and retention in both undergraduate and graduate programs have increased.

\section{CONCLUSIONS}

The application of the five abilities is a lesson plan for successful sustainability. Availability ensures access to the right technology, materials, facilities, tools, and people. The new network culture has led to the development of online education and made higher education more accessible worldwide. While availability brings students and faculty to a university, consistency and reliability make them stay. Dependability increases student retention and student retention is a main goal of a university. Clear, definable measurements tell the university if it is achieving its goals. Performance should be graded and its renowned capability/performance should lay the foundation for future research, revenue, and success. While the current price tag of American higher education is hardly sustainable, reducing costs and increasing financial aid can augment higher education's endurance by making it affordable. Further, higher education institutions can be held accountable to maintain defined student retention and graduation rates if they receive government funding and their students can get government subsidized loans. Publicizing an institution's financial, academic, and social successes enhances the institution's overall marketability. Higher education must start with clear, measurable goals and a team to constantly monitor and refine these goals. Promoting an institution's competitive advantage with consistent branding will also enhance the sustainability of higher education institutions. 
According to Andy Hargreaves, author of Sustainable Leadership, "Change in education is easy to propose, hard to implement, and extraordinarily difficult to sustain (Hargreaves, 2006)." Colleges need to utilize their current resources while generating future, profitable venues and preparing students for future careers. The road to sustainability is ever-changing and the key to success is change, especially when the change is needed for survival and can be achieved by applying the lesson plan for sustainability.

\section{AUTHOR INFORMATION}

Elizabeth Driscoll received her Bachelor's Degree from Boston University and a Master's in Business Administration from the University of Massachusetts Lowell. She now works as an Account Executive for the Oracle Corporation in Burlington, Massachusetts.

Clare L. Comm is Professor of Marketing in the College of Management at the University of Massachusetts Lowell, where she specializes in services marketing and buyer behavior. She received a Ph.D. in marketing from the University of Cincinnati. She has written numerous articles in the area of the marketing of services and sustainability (higher education and the airline industry). She is a co-author of a book on sustainability: Sustaining the Military Enterprise: Enhancing its Ability to Perform the Mission, ISBN: 978-1-4200-7858-9, with J. Manary and D. Mathaisel, CRC Press, Taylor \& Francis Group, October 2009. E-mail: clare_comm@uml.edu

Dennis F.X. Mathaisel is Professor of Management Science at Babson College. He received his Ph.D. from MIT and was a Research Engineer in the Department of Aeronautics \& Astronautics at MIT. His research is focused on enterprise sustainability. He is the author of three books: Sustaining the Military Enterprise: Architecture for a Lean Transformation, Auerbach, Taylor \& Francis Group, 2007; Sustaining the Military Enterprise: Enhancing its Ability to Perform the Mission, with J. Manary and C. Comm, CRC Press, 2009; and Engineering for Sustainability, with Joel M. Manary and Ned H. Criscimagna, CRC Press, September 2012. E-mail: mathaisel@babson.edu (Corresponding author)

\section{REFERENCES}

1. Altbach, P., Berdahl, R., Gumport, P. (1999), American Higher Education in the Twenty-first Century: Social, Political and Economic Challenges, The John Hopkins University Press, Maryland.

2. Auxter, T. (2010), "Radical Transformations in Higher Education: Where Do We Go From Here?" Thought \& Action. Volume 26.

3. Center for College Affordability and Productivity, (2010), "Chart of the Week: Rise in Real College Costs" October.

4. Eddy, J., Murphy, S. (1998), Current Issues in Higher Education: Research and Reforms, University Press of America, Maryland.

5. Ellis, R., Goodyear, P. (2010), Students' Experiences of E-Learning in Higher Education: The Ecology of Sustainable Innovation, Routledge, New York.

6. Fischer, K. (2010), "America Falling: Longtime Dominance in Education Erodes," The Chronicle of Higher Education 56.7, September.

7. Forrant, R., Pyle, J. (2002), Globalization, Universities and Issues of Sustainable Human Development, Edward Elgar Publishing Limited, Massachusetts.

8. Gregory, J., Wiechmann, J. (1993), Marketing Corporate Image: The Company as Your Number One Product, NTC Publishing Group, Illinois.

9. Hargreaves, A., Fink, D. (2006), Sustainable Leadership, Jossey-Bass, California.

10. Hostrop, R. (1983), Managing Education for Results, ETC Publications, California.

11. Karabell, Z. (1998), What's College For? The Struggle to Define American Higher Education. Basic Books, New York.

12. Lazonick, W. (2009), Sustainable Prosperity in the New Economy: Business Organization and High-Tech Employment in the United States, W.E. Upjohn Institute for Employment Research, Michigan.

13. Lenzner, R., Johnson, S. (2010) "Seeing Things as They Really Are," Forbes.com, November.

14. Leonhardt, D., (2011) "Cut Waste or Invest? Try Both," The New York Times Business, January 26.

15. Levine, A. (1994), Higher Learning in America: 1980-2000, The John Hopkins Press, Maryland. 
16. Mathaisel, D., Manary, J., Comm, C. (2009), Enterprise Sustainability: Enhancing the Military's Ability to Perform Its Mission, CRC Press, Florida.

17. Mazzarol, T., Soutar, G. (2001), The Global Market for Higher Education: Sustainable Competitive Strategies for the New Millenium, Edward Elgar Publishing Limited, Massachusetts.

18. Moloney, J. (2010), Interview, Executive Vice Chancellor, University of Massachusetts Lowell, Lowell, Massachusetts, November 16.

19. Pew Research Center, (2011), Nationwide telephone survey of 1,055 university presidents and 2,142 other adults conducted on landline and cellular phones, March 15-April 24.

20. Riesman, D. (1998), The Academic Enterprise in an Era of Rising Student Consumerism: On Higher Education, Transaction Publishers, New Jersey.

21. Selingo, J. (2012), "Fixing College," New York Times, June, 26.

22. Taylor, M. (2010), Crisis on Campus, Alfred A. Knoff, New York.

23. U.S. Department of Education Institute of Education Sciences: Digest of Education Statistics, (2005), March.

24. Westmeyer, P. (1985), A History of American Higher Education, Charles C. Thomas, Illinois. 
NOTES 